\title{
ASSET PRICES - AN AUSTRIAN PERSPECTIVE
}

\author{
PHILIPP BAGUS*
}

Abstract: How asset prices should be taken into account in monetary policy is a controversial question in mainstream discussion. These mainstream positions can be differentiated into two broad perspectives: the proactive and the reactive views. The proactive view advocates pricking the asset price bubble, while the reactive view argues against monetary policy targeting asset prices. In this article the relation between asset prices and the Austrian business cycle theory is examined. Following this, a critique of both the proactive and reactive views is provided and implications for monetary policy are deduced.

Key words: Austrian Economics, Business Cycles, Asset Prices, Central Banks and their Policies.

JEL Classification: B53, E32, E58.

\section{I \\ INTRODUCTION}

How monetary policy should account for asset prices is a controversial question in mainstream discussion. The most contentious point is whether a restrictive monetary policy should be used to prick speculative asset price bubbles. The new chairman of the Federal Reserve System (the Fed), Ben Bernanke, along with Mark Gertler ${ }^{1}$ are two well-known representatives of those economists who argue against a preventive pricking of

* Asst. Professor of Political Economy, Universidad Rey Juan Carlos, Madrid. I would like to thank Francesco Carbone, José Ignacio del Castillo Martínez and Dr. Guido Hülsmann for their helpful comments and discussions.

1 See Bernanke and Gertler (2000), p. 4. 
asset price bubbles. ${ }^{2}$ These economists point to the difficulties a central bank would have in identifying a bubble. They doubt that a central bank could manipulate the interest rate so precisely as to allow the speculative air to leak slowly from the asset price bubble. They fear, rather, that the restrictive monetary policy would burst the bubble and lead to a harsh and dangerous recession. Hence, a central bank policy that tries to manipulate asset prices is dismissed. According to this view, asset prices should only play a role in monetary policy insofar as they are an indicator of future price inflation. This kind of asset price consideration would be wholly sufficient. ${ }^{3}$ The Bernanke view can be called the reactive view because the central bank watches the asset price bubble grow, and once the bubble bursts, recommends expansive monetary policy in order to stabilize asset prices.

However, there is a view which opposes the reactive view. The opposing side recommends a proactive approach, ${ }^{4}$ arguing that it is, at least in some cases, appropriate to prick asset price bubbles. Cecchetti and his colleagues maintain that it is no more difficult to identify an asset price bubble than it is to estimate other parameters considered relevant for the central bank, like potential output, for instance. ${ }^{5}$ Concern about financial instability is the main reason for recommending a proactive stance. ${ }^{6}$ Proponents of a proactive approach hope that such a policy might help to prevent an asset price market crash, which might, without this intervention, destabilize the financial system. Following a crash of the stock, bond, or housing markets, balance sheets of banks and corporations might deteriorate and private households might reduce consumption. As a result, the credit allocation might be severely disrupted. This phenomenon is

2 Two proponents of this opinion are Svensson (2002), p. 289 and Greenspan (2002), p. 5.

3 See Bernanke and Gertler (2000), p. 4 and Svensson (2002), p. 289.

4 This side includes Cecchetti et al. (2000), Bordo and Jeanne (2002), Borio and Lowe (2002).

5 See Cecchetti et al. (2000), p. 2.

6 See Berger, Kißmer and Wagner (2005), p. 2; and Bordo and Jeanne (2002), p. 5; Borio and Lowe (2002), p. 23. 
called a "credit crunch» which is basically another term for credit contraction. The credit crunch leads to severe consequences for enterprises which depend on further credits. Enterprises then go bankrupt. This in turn can lead to further reduction of consumption and further deterioration of bank balance sheets. When banks begin turning to bankruptcy due to bad loans, systemic stability is at risk. The whole monetary system threatens to collapse. The proactive pricking of bubbles is therefore thought to prevent this danger to the stability of the financial system. A second argument for a proactive strategy, sometimes mentioned, is the danger of misallocation of real resources caused by an asset price boom. ${ }^{7}$ In this context, the argument is attributed to the Austrian School of economics. However, extensive elaboration about the complex relation between Austrian theory and the problem of asset prices is not provided. Most importantly, the Austrian school itself has not provided a systematic analysis of the problem of asset prices and monetary policy. ${ }^{8}$

In this paper, I examine what the Austrian business cycle theory $(\mathrm{ABCT})$ can contribute to our understanding on the asset price problem. Such an analysis requires the development of a systematic Austrian perspective concerning asset prices. With this in mind, the paper is divided into four sections. The first section provides an analysis of the role of asset prices in the Austrian business cycle theory. The second section draws a connection between credit expansion and asset price bubbles. The third section offers a critique of both the proactive and reactive strategies in dealing with asset-price bubbles. The fourth section contrasts these mainstream policy prescriptions with monetary policy recommendations derived from Austrian theory.

7 See Gruen and Plumb and Stone (2002), p. 13; and Conrad and Stahl (2002), p. 490 .

8 See Borio and Lowe (2002), p. 27, and Bordo and Wheelock (2004), p. 19; Conrad and Stahl (2002), p. 490. Skousen (2005), p. 286 observes a growing interest in the Austrian view on asset prices. There has been a more general study by Machlup (2002) about the stock market. Mueller (2001) and Huerta de Soto (2006) have written about bubbles. However, no exhaustive and systematic analysis about ABCT and asset prices has been undertaken. 


\section{II \\ A THEORY OF CREDIT EXPANSION AND ASSET PRICES}

\section{Asset prices and the business cycle}

According to the $\mathrm{ABCT}$, the business cycle is caused by an increase in the amount of money by the banking system via credit expansion. This credit expansion leads to an interest rate that is too low in comparison with the preferences of the market participants. ${ }^{9}$ Due to the relative reduction of the interest rate, entrepreneurs are led to think that the amount of savings has increased. In turn, they engage in new investment projects, beginning more investment projects than can be finished with available means of production. Interest rate reductions have more of an effect on investment projects that take more time to be completed than on projects that take less time to be finished. Hence, many investment projects are begun that take relatively much time to produce consumer goods. The crucial point is that investors are led to undertake more investment projects than otherwise, acting as if savings had increased, increasing the demand for producer goods.

When the owners of the factors of production get paid with the newly created money and spend their income in the old consumption-savings ratio, (i.e., they do not increase their savings), there will be a relative increase in the demand for consumer goods. Moreover, the supply of consumer goods slows down. This is due to the undertaking of investment projects that yield consumer goods only after a longer time period than for projects that would have otherwise been undertaken. The relative increase in demand for consumer goods and the relative decrease in their supply allow the prices of consumer goods to rise. Consequently, the increase in the consumer goods prices increases profits in consumer goods industries in comparison to capital

9 This is not necessarily so as Hülsmann (1998), p. 4 has shown because the impact of the new money on prices might be anticipated by entrepreneurs and included in the interest rate. 
goods industries. Losses in capital goods industries may arise as well. It becomes evident that not all investment projects that were begun can be completed with the available means of production and a recession sets in. Mainly investment projects that consume much time, i.e., in the higher stages of production, have to be abandoned and factors of production are then shifted back to less time-consuming projects, to the lower stages of production, which produce consumer goods more quickly and yield higher profits. The recession ends when the investment projects come into line again with the preferred consumptionsavings ratio of the market participants.

Now what role do asset prices play in an artificial boom caused by credit expansion?

There are several effects of the credit expansion on asset prices. ${ }^{10}$ First, the credit expansion has an effect on capital goods prices and thereby, on asset prices. As already mentioned, the credit expansion leads to a reduction of the interest rate in the loan market. ${ }^{11}$ Entrepreneurs will use this lowered interest rate to discount the expected returns of the capital goods, which results in a higher net present value of the capital goods. ${ }^{12}$ The net present value of stocks, bonds, and real estate, which represent capital goods, is increased by the lowered interest rate as well.

10 In this essay, I focus on prices of financial assets like stocks, bonds and real estate. Investors buy financial assets either to collect rent, interest, or dividends, or to sell them at a higher price later. As such, raw materials can become financial assets at certain times. Accordingly, in the 1970s, for example, investors bought petroleum as a financial asset. Recently, raw materials seem to assume the role of financial assets again.

11 More precisely, the interest rates decline relatively, i.e., they will be lower than they would have been without credit expansion. Hence, the historic fact that in economic booms the nominal interest rate tends to increase does not affect the analysis. In the rest of this article, all changes should be regarded as relative. And again, the reduction of the interest rate is not necessary since entrepreneurs could anticipate the effect the credit expansion has on prices.

12 See Huerta de Soto (2006), p. 278-279. However, future returns will be discounted by the interest rate that is thought to prevail at each respective point of time. The longer the fall in the interest rate is thought to last the stronger will be the effect on net present values. In the end, we are dealing with the illusion of the market participants that the interest rate can be lowered permanently by monetary policy, thereby making the bubble possible. 
As a result, entrepreneurs will bid up the prices of stocks, bonds, and real estate to their new, higher net present value.

A second effect works towards a soaring of stock and real estate prices. Investment projects, that with a higher interest rate would have been unprofitable, now look profitable due to the interest rate reduction. In order to undertake these investment projects, capital goods are needed. Therefore, as new credit is created, capital goods are demanded. However, if savings do not increase, neither does the supply of capital goods. The increase in the demand for capital goods meets a supply of capital goods that has not increased. Consequently, the prices of capital goods will be bid up. Consequently, the price of capital goods titles and the price of their production facilities also increase. ${ }^{13}$ Stocks are titles to capital goods and production facilities of capital goods. Houses are capital goods to the degree that their services are consumed in the future. Bond prices also depend on the market value of capital goods, since when the market value of capital goods and of the company issuing the bonds increases, the perceived probability of the company meeting its bond obligations might increase. Indeed, «bond-holders (long-term creditors) are just different types of owners» ${ }^{14}$ of the company. Hence, the prices of stocks, bonds, and real estate soar. An asset price boom begins.

After the asset price boom has been triggered by credit expansion, it is fueled by waves of optimism pervading the whole economy. This optimism, instead of fueling all asset prices simultaneously, might concentrate on one or more of these areas, i.e., stocks, bonds, or real estate. It is possible that the optimism is so enthusiastic that it is thought that a new era of never-ending growth has begun, often symbolized by a new technology. ${ }^{15}$ The

13 See Machlup (2002), p. 188.

14 See Rothbard (2000), p. 51.

15 Historical examples are the boom of the 1920s' stock market and the «New Economy» boom in the late 1990s where new technologies played a major role. In the 1920s, commercially available electrical power and the radio, a new media device, represented the boom while in the late 1990s information technology and, more specifically, the internet, another communicational innovation, promised a new age. On the «New Economy» boom see Callahan and Garrison (2003). 
new technology leads to the expectation that future profits will increase strongly, which increases the expected net present value.

Later, optimism might be fed by three sources. First, the accounting profits will increase during the boom. As Mises points out (1998, p. 546):

If the annual depreciation quotas are determined in such a way as not to pay full regard to the fact that the replacement of wornout equipment will require higher costs than the amount for which it was purchased in the past, they are obviously insufficient. If in selling inventories and products the whole difference between the price spent for their acquisition and the price realized in the sale is entered in the books as a surplus, the error is the same.

Hence, the illusionary gains of businesses seem to indicate not only that everything in the economy is fine but also that there is a period of great prosperity and real growth. This further increases the optimism. Therefore, due to the illusionary gains, people might invest more in asset price markets and thereby throw new oil into the fire of the asset price boom.

Second, during this boom, the belief often spreads that credit expansion makes an increase in production possible without having to forego consumption. ${ }^{16}$ A euphoria diffuses in the economy. One thinks that production can be increased without having to save in the first place. The rising security and housing prices seem to support this belief. Therefore, the security market and real estate investors are willing to continue the entertaining speculation if credit expansion continues to flow and consumption does not need to be restricted. ${ }^{17}$

Third, the optimism is self-enforcing, in a way, since the rising asset prices attract more investors to asset price markets. People might quit their jobs to dedicate themselves to asset price market speculation, where profits seem to be made automatically and in an easier way than in their old jobs. Entrepreneurial creativity and effort are shifted towards asset price markets. As a consequence

16 See Huerta de Soto (2006), p. 280-281.
17 See Machlup (2002), p. 95. 
of the money flowing into the asset price markets, prices continue to soar, increasing the optimism even further. ${ }^{18,19}$

Optimism is not the only reinforcement for an increase in speculative prices. The boom can reinforce itself in another way. This occurs when the asset price boom receives positive feedback from the credit expansion and thereby boosts further malinvestments both in the asset price markets and the real economy. There are two possible reasons for this feedback. First, the higher asset prices, i.e., higher security and housing prices, can be used by companies as a collateral for further credits. ${ }^{20}$ Moreover, there might be the illusion of an increase in real wealth by the increase in asset prices. ${ }^{21}$ Under this illusion, market participants reduce savings and demand further credits. The bond market is a vivid example of this effect. When interest rates are artificially lowered by the credit expansion, the prices of bonds tend to rise. Market participants might get a false impression that their real wealth has increased. Believing that the asset price

18 In this article I focus on analyzing a closed economy. However, in the real world, the optimism can spread to other countries leading to another flow of purchasing power to the asset price markets stabilizing the exchange rate (which is psychologically important) in spite of deficits in the balance of trade.

${ }^{19}$ An interesting characteristic of the asset price boom is that as time goes by it becomes ever more dependent on the optimism that feeds it. When asset prices are not inflated by credit expansion, changes in the psychology of market participants do not play an important or determining role in asset price fluctuation. More specifically, psychological changes by themselves do not cause a crash, but only reflect changes in expectations about the real economy. For example, when there is fear of war, prices are likely to collapse. In contrast, during periods of credit expansion and asset price booms the psychology of market participants eo ipso suddenly becomes important for the changes in asset prices. A small deterioration of the fragile euphoria of the «new times» can endanger the asset price boom, triggering a reinforcing downturn. This downturn can be triggered for almost any reason, e.g., losses in some industries, elections, political conflicts, or new government interventions. Such a downturn may stop only when asset prices return to net present values not distorted by credit expansion.

20 See Huerta de Soto (2006), p. 362. The new international accounting standards (IFRS) greatly improve this feedback mechanism since assets have to be accounted for with their market value (instead of the purchase price) which increases during an asset price boom. The IFRS breaks with the prudence and caution of the institution of accounting practices that have evolved freely for more than a thousand years in the market. See also Huerta de Soto (2003).

21 This effect is sometimes called «wealth effect.» See, for example, Goodhart and Hofmann (2004), p. 175. 
markets somehow «save» for them, they stop saving. However, this is an illusion since the real amount of goods is not increasing. Since their nominal wealth seems to steadily and automatically increase they increase consumption on the cost of savings. Concerning stocks and real estate markets, Mises (1998, p. 54647) makes the following observation:

If the rise in the prices of stocks and real estate is considered as a gain, the illusion is no less manifest. What makes people believe that inflation results in general prosperity is precisely such illusory gains. They feel lucky and become openhanded in spending and enjoying life. They embellish their homes, they build new mansions and patronize the entertainment business. In spending apparent gains, the fanciful result of false reckoning, they are consuming capital.

Why would one save if one becomes wealthier every year? Market participants might even go into more debt to invest in the bond market, buying seemingly no-risk assets as government bonds, thereby increasing bond prices further. Hence, it can be concluded that the asset price boom tends to feed and reinforce itself with further credit expansion.

It should be emphasized that the asset price boom also has an important effect on entrepreneurial culture, because a new type of entrepreneur will become successful in the boom. As Mueller states (2001, p. 14):

With the continuation of such a boom, prudence diminishes, and new types of entrepreneurs appear, who neglect profits in favor of market share and who eagerly apply the latest standard of technology irrespective of a prudent evaluation of their economic merits. As money can be gained easily with speculation on asset price markets the entrepreneurial capacities are directed towards speculation and making fast profits at asset price markets.

While the optimism about new technologies and the booming economy spreads, it is possible that enterprises that maximize revenue and use new technology will experience extraordinarily 
soaring stock prices. Hence, short-term thinking is rewarded at the cost of long-term thinking and a prudent, conservative entrepreneurial culture. Seeing the possibility of quick profits, people become more present-oriented, i.e., their time preference increases. They begin to think, and are actually proven right during the boom, that no hard work or thought is necessary to make profits. Just pick any stock and it will go up. Hence, work ethic declines and a culture of «no sacrifice» develops. Entrepreneurial energy is dedicated to making fast profits in the asset price markets. Wanting to earn money as quickly as possible, people fill their daily conversations with the latest asset price market news. They develop and acquire knowledge that helps them to participate in an asset price boom fueled by credit expansion. This knowledge will become worthless when the credit expansion ends. When the bubble unexpectedly bursts, the entrepreneurial culture and confidence of a whole generation will be severely damaged, demoralizing a whole generation. The increase in time preference rates will have lasting social effects and start a process of decivilization. ${ }^{22}$

Moreover, the general population might become repelled by the stock market. Individuals do not learn to invest long-term in the stock market, thereby preventing the development of a «society of proprietors.» A «society of proprietors» serves as a battering ram against any government intention to intervene in the economy, because when companies are harmed by government interventions proprietors will protest. The recurrent booms and busts within the asset price market, therefore, can be considered as a major drawback to a free society.

\section{Delay of malinvestments by a stock market boom ${ }^{23}$}

Another point in relation to credit expansion and the stock market is important. It is by all means possible, that the new credits are not given directly to entrepreneurs who would use them to engage

\footnotetext{
${ }^{22}$ For the influence of time preference on the process of civilization, see Hoppe (2001).

${ }^{23}$ The same analysis applies mutatis mutandis for a real estate, bond market, or raw materials boom.
} 
in investment projects, of which all could not be completed. Instead, the new credits might then be used by those speculating in the stock market. The newly created fiduciary media are injected first into asset markets and from there, under certain circumstances, and only after some interval, they then begin to spread over the whole economy.

It is possible that the new credits, flowing into the stock exchange would be used in a speculation chain. In other words, the credits would be used to buy stocks, and then the sellers of the stocks would use this money to invest in the stock market and so forth. It is therefore conceivable that at least for some time the credit expansion is "absorbed» by the stock market. ${ }^{24}$ In fact, as long as the illusion persists that a new era has begun, the credit expansion can accumulate in the stock market. Hence, as long as the stock market absorbs the credit expansion, resources are not intertemporally misallocated therefore delaying the business cycle. The reason for this is the absence of additional investment projects undertaken that cannot be ended with the available means of production. ${ }^{25}$ It is as if new money is being pumped into a casino. As long as the new money is used for ever newer games in the casino it is stored up there. Only indirectly, by changes in the perceived wealth, would the games in the casino have effects on the prices beyond its tables.

Moreover, not only can speculation in the stock market delay the recession, but it can even ease the recession. As was stated above, a recession sets in when owners of the factors of production receive newly created money and spend in the old consumptionssavings ratio. Savings are too meager for the completion of the longer production processes. A stock market boom can increase savings and thereby ease and delay the recession. This attenuation becomes possible when the speculators do not increase their consumption but, due to the euphoria at the stock market,

24 See Machlup (2002), p. 54.

${ }^{25}$ However, market participants might perceive their wealth in a different manner and consequently change their time preference rate. In this case, the structure of production would be changed in a sustainable way. However, there would still be no artificial boom. 
consume less, save more, and invest more of their income in the stock market. ${ }^{26}$ Due to the relative increase in savings, the relative increase in consumer goods prices that introduces the recession is watered down. The adaptation in the recession is then smaller than it would have been otherwise. However, even though this attenuation might be theoretically possible, it is not necessarily probable in later stages of the boom. As our analysis of the «wealth effect» and «illusionary gains» has shown, consumption might actually increase in relation to savings due to the illusion that the asset price boom signifies higher real wealth. For example, the low savings rate in the U.S. indicates that recent asset price booms have stimulated consumption instead of savings.

It must be emphasized that even though the stock market boom might ease the recession and delay an artificial boom in the real economy, malinvestments in the real economy are likely to occur. The boom-bust cycle is likely to set in, since the absorption of the newly created credits in the stock exchange cannot last forever. ${ }^{27}$ Sooner or later, the credits leak from the stock exchange into real production. There are two reasons for this. ${ }^{28}$ First, the rising stock prices will incite new issues of stocks as an inexpensive way to finance new investment projects, since the costs of financial capital are reduced by the rising stock prices. Second, entrepreneurs will be encouraged to sell their higher stocks in order to invest in new projects. ${ }^{29} \mathrm{New}$ investment projects will now have become attractive since the credit expansion leads to relatively lower interest rates. Finally, investments will be greater than the available means of production needed to complete all of the initiated projects. The credit expansion in this case will have simply taken a detour around the stock market. This detour can greatly lengthen the period from

26 See Huerta de Soto (2002), p. 361.

27 See Machlup (2002), p. 100.

28 See Machlup (2002), p. 51-53.

29 It is also conceivable that stocks are sold to finance current consumption. In this case, consumer goods prices rise and resources will be shifted from longer investment projects to the consumer goods industries. There is a tendency towards a shortening of the structure of production. This can induce the recession or limit the amount of further malinvestments. 
the beginning of the credit expansion to the bust. Hence, the existence of temporarily absorbing asset price markets can account for the length of historical boom-bust cycles.

\section{Credit expansion as a necessary condition for a sustained asset price boom - the central banking and asset price stabilization illusion cycle}

In a free market economy, savings flow slowly and steadily to the stock market. ${ }^{30}$ The incentives to liquidate and engage in stock market investments tend to balance. If the price of a stock is below its net present value, entrepreneurs will buy the stock, while they will sell it when it is above its net present value. Therefore, persistent security booms or real estate booms are normally not possible. For example, by itself, the «technology shock» cannot incite a persistent boom. It must be nourished and fed by credit expansion. Only a credit expansion facilitates a persistent and euphoric security boom of all industries, including the consumption good industries. ${ }^{31}$

Without an ongoing credit expansion the stock market boom would end soon for two reasons. First, when stock prices soar, market participants, especially professional speculators, will dissolve their holdings. Stock prices will tend to fall back to their net present value. Second, entrepreneurs will exploit the high stock prices and issue new shares. The number of initial

\footnotetext{
${ }^{30}$ Again we concentrate on the stock market. But again, the analysis applies mutatis mutandis for the bond and real estate markets.

31 A possible but improbable steady decline of time preference rates and a consequent increase in savings and decline of the interest rates would only enable a boom in capitalist goods industries. The increase in savings would be depressing for consumer goods industries. Of course, increases in the money supply, for instance, newly mined gold in a gold standard would increase stock market prices as well. However, this would hardly be considered a sustained stock market boom where stock prices increase relative to commodity prices. The only possibility imaginable is the occurrence of an irrational optimism of virtually all market participants, erring on future earnings and interest rates. The only possibility for such clusters of entrepreneurial errors seems to be caused by a credit expansion. For the problem of clusters of errors, see Hülsmann (1998).
} 
public offerings will increase, and the increasing supply of stocks will generate a tendency towards falling stock prices. But why do these two reasons not apply to a stock market boom fueled by credit expansion? More concretely, during a credit expansion why do professional speculators not immediately end an asset price boom by selling stocks or even short-selling the overvalued stocks? The answer is straight-forward: the problem for these speculators is that they do not know when the credit-driven boom will end. ${ }^{32}$ They might even try to short-sell stocks. However, with this strategy, they will be losing money continuously if the credit expansion continues. In addition, the continuing credit expansion will supply the liquidity to absorb new public offerings.

For this reason, bubbles become possible only because the endurance and the extension of the credit expansion are uncertain. Credit expansion therefore, greatly enlarges the volatility of asset price markets. Credit expansion makes asset price bubbles and busts not only possible, but probable. Even the professional investors, who normally have an equilibrating effect on price volatility, participate in the speculation, trying to guess when credit expansion ends, making profits during the bull market and then leaving the market before it crashes.

However, the uncertainty of the extent of the credit expansion might explain why professional investors participate in evolving bubbles, but this uncertainty does not explain sufficiently why there are clusters of malinvestments in asset price markets in the first place. In particular, we must answer the intriguing question: why do investors in asset price markets repeatedly commit clusters of errors which result in asset price bubbles? The answer is simply a lack of theoretical knowledge. A widespread belief exists, that with the artificial reduction of the interest rate, unending growth of the real economy and asset price markets is possible. It is believed that the stabilization of asset prices by the central bank could be achieved and would actually be in the interest of all market participants. Hence, market participants do not see any reason why a superficially booming stock market or

32 See Machlup (2002), p. 96. 
real economy might be endangered by credit expansion. ${ }^{33}$ They just do not understand that they are facing an artificial, creditdriven boom, (i.e., they are not aware of the ABCT and its implications for asset price markets). Therefore, they invest in asset markets not realizing that they might be committing errors. The rising and bursting of the asset price bubbles might then also be called an asset price stabilization illusion cycle.

Even after asset prices crash, the illusion prevails that credit expansion and the central bank's managing of asset prices is in the interest of market participants. Especially the propping up of asset prices by further credit expansion is thought to be beneficial. This illusion keeps the credit expansion, which was absorbed by the stock market, from being entirely wiped out in the recession. Stock prices might not fall back to their net present values since it is expected that the «beneficial» credit expansion will continue. As a result of this illusion, it is possible that with new cycles, a growing base of credit expansion remains absorbed in the asset price markets.

\section{Ever increasing doses of credit to fuel the boom}

As a credit expansion is necessary to start a bubble in the first place, ever higher doses of credit are necessary in order to keep the boom going. There are two main reasons for this. The first reason can be explained by the fact that the credit expansion begins to flow into the real economy at some point, initiating a business cycle and raising consumer goods prices to levels that are higher than they would have been without credit expansion. More specifically, consumer prices rise for several reasons. First, consumer goods prices rise, because incomes of the owners of the factors of production rise due to the new money spent in new investment projects. The owners of the factors of production spend this new monetary income partly on consumer goods. Second, during the boom phase new investment projects are

33 For the role that plays illusion in error cycles, see Hülsmann (1998). 
undertaken. These projects take longer to yield consumer goods than the projects that were undertaken before. Hence, the flow of consumer goods slows down, resulting in a tendency towards higher consumer goods prices. Third, due to the rising stock prices, people might be induced to sell their stocks and take delight in increased consumption, since they regard their real wealth as having been increased. As a result, profits in stock speculation might not be used for reinvestment but for consumption instead, leading to a consumption of capital. ${ }^{34}$

The need for ever increasing doses of credit can be explained now by the increase in consumer goods prices. If the social time preference rate does not change, stock market participants will not be willing to restrict consumption when consumer prices increase. They will not continue speculation and will sell their holdings to pay for the higher consumption goods prices. However, the stock market prices might be prevented from falling if the stock market participants receive additional money for speculation through additional loans. ${ }^{35}$ This new credit expansion will lead to a further reduction in the amount of consumer goods and an increase in consumer goods prices, thus increasing the need for an even higher dose of credit to prevent a stock market collapse. It is important to emphasize that, as consumer prices continue to go up, higher - and not merely proportional- doses of credit are required. This is because, at some time, the newly created money is spent on a shrinking amount of consumer goods.

Yet, increasing the doses of credits ad infinitum without destroying the monetary system is not possible. As consumers become aware of the ongoing inflation and the fact that the availability of consumer goods is decreasing, they will rush to buy consumer goods. They will sell their stocks for money and sell their money to buy consumer goods. If the doses of credit expansion are increased continuously, the process will finally end in a runaway hyperinflation with the break-down of the monetary system. ${ }^{36}$

\footnotetext{
34 See Hayek (1934), p. 133.

35 See Machlup (2002), p. 95.

36 See Rothbard (2001), p. 875-877.
} 
Another factor that can cause the stock market boom to collapse is an increase in the nominal interest rate. An increase in the nominal interest rate would endanger the stock market boom (and even more strongly the bond market boom) since the future earnings would have to be discounted more strongly. The gross market interest rate contains a premium for the expected price increase. As prices begin to increase, people will expect further price increases and, accordingly, the gross market interest rate will rise. Investors will tend to interpret as a negative sign. A possible means of watering down this increase in the gross market interest rate is further credit expansion. Since prices will rise further as credit expansion doses become higher, the doses of credit needed to avert an increase in the nominal interest rate must become even higher. Yet, the likelihood of watering down the increase in the gross market rate over a long period of time is doubtable. This is because market participants will probably not remain ignorant of the increased credit expansion. Anticipating this, they will increase their interest rate bidding. ${ }^{37}$

The stock market boom requires a continually higher increase in doses of credit. When this does not happen, consumer goods prices increase relative to producer goods prices, leading the stock market participants to sell their holdings. The belief in a continuous stock market boom fueled by credit expansion is shaken and a bear market sets in. The distortions between real savings and investments that were caused by the credit expansion become apparent in the stock market where clusters of investment and speculation errors manifest themselves. The stock market

37 The reasons why interest rates have not increased substantially in the last years, notwithstanding the credit expansion, might be twofold. First, the liberalization of the foreign trade of former communist or socialist countries China and India led to an increase in the production of consumption goods. Second, the mercantilistic policies of China and Japan which have increased their dollar reserves. The combination of both lead to relatively stable consumption good prices which would have increased less or even fallen otherwise. Hence, interest rates did not explode despite the credit expansion. The price premium was therefore somewhat «hidden» since the credit expansion was partly compensated by the above mentioned factors. I owe this insight to Guido Hülsmann. He notes that productivity increases or growth can therefore hide the "price premium," making long booms possible. 
is, therefore in a sense, a mirror of the real economy. As a mirror of the real economy, stocks of capital intensive enterprises will suffer higher losses than enterprises that produce consumer goods or goods that are relatively less capital intensive.

III

MONETARY POLICY AND ASSET PRICES

\section{Critique of the proactive view}

After a theoretical analysis of the asset price issue, I now would like to provide a critique of both mainstream views concerning the appropriate monetary policies towards asset prices. Following this, I will propose an Austrian view on this debate and address the question of whether problems are posed by asset prices for monetary policy. First, there are several points concerning the proactive view on monetary policy. The proactive view, at least in some cases, advocates the pricking of asset price bubbles. As Cecchetti $(2002$, p. 2) states about the failure of the Federal Reserve to prick the internet bubble:

Taking explicit account of the bubble by tightening is a sound alternatice. To the extent that bubbles arise from unrealistic expectations of future economic growth, interest-rate increases that moderate current levels of growth can put a break on them. I believe that we are now paying the price for the Federal Reserve's failure to contemplate such action in the spring of 1997. If the Fed had raised interest rates even only slightly - 0.50.75 percentage points, say- it would have put a modest break on growth, reduced reported corporate profits and lowered estimates of future revenue growth. With a slower growth forecast, the stock price bubble may have been less extreme.

One should also keep in mind that the aim of the proactive view in raising the interest during a bubble expansion is to secure financial stability. For example, Borio and Lowe (2002, p. 22) make the following comment: 
If the risk of this occuring [inflation-targeting regimes not responding sufficiently to threat to the financial system] is significant, then a slightly modified policy regime, under which the central bank responds not only to short-term inflation pressures but also, at least occasionally, to financial imbalances, may ultimately deliver a better combination of monetary and financial stability. Under such a regime the central bank might opt for higher interest rates than are justified simply on the basis of the short-term inflation outlook if there are clear signs of financial imbalances, such as if credit growth is rapid and asset prices are rising quickly. The justification for doing so could be that the higher interest rates could help contain the financial excesses, and in so doing reduce the probability of future financial instability and possibly a sustained undershooting of the inflation objective. (Italics added)

An interesting implication of the proactive view is its limitation of credit expansion. This limitation may also limit the extent of a real recession. Proactive policy recommendations are less expansionistic than reactive recommendations. However, the theory behind the proactive view is fallacious. ${ }^{38}$ The proactive view argues that the bursting of larger bubbles might lead to a deterioration of bank and company balance sheets. Companies then will have difficulties getting further credits. A credit crunch sets in. This, in turn, will lead to the bankruptcies of companies that rely on further credits. Bankruptcies will ensue, further deteriorating bank and company balance sheets. To ensure liquidity, banks will restrict further credits. As a bank's balance sheets deteriorate, a bank run might occur, which in turn can lead to further bank runs, placing the whole monetary system in danger. ${ }^{39}$

While the reasoning is technically correct, the problem is that the proactive view, as well as the reactive view, considers the stock

38 The assumptions underlying the proactive view are shared by the reactive view. The difference between the two is that the proactive view is more optimistic concerning the capability of the central bank to manage asset prices.

39 For the reasoning behind the proactive view, see Bordo and Jeanne (2002); or Borio and Lowe (2002). 
market crash as the cause of the downturn or recession. ${ }^{40}$ More specifically, the credit crunch is seen as a worsening factor in the recession. Yet, the ultimate cause of the recession is the credit expansion that created the distortions in asset price markets and the real economy. The stock market crash only manifests the malinvestments that have already occurred. Moreover, triggering a credit crunch speeds the recovery. There are two main reasons for this. First, people might save more. The cause of the recession is a lack of savings in relation to consumption, so that not all investment projects that were begun can be finished. It is indeed possible that through the credit crunch, consumption shrinks relative to savings. Feeling themselves to be poorer because the market values of the assets they hold have collapsed, individuals might save more. Moreover, falling prices in the economy might lead to an accounting illusion. As Rothbard (2000, p. 17-18) puts it:

In a deflation the accounting illusion is reversed: what seems like losses and capital consumption, may actually mean profits for the firm, since assets cost now much less to replace. This overstatement of losses, however, restricts consumption and encourages saving; a man may think he is merely replacing capital, when he is actually making an added investment in the business. ${ }^{41}$

Hence, the overstatement of losses and the collapse of asset prices might induce a restriction of consumption and an increase in savings. The recession, which has been caused by a lack of savings, is now made shorter and less severe.

Second, the restriction of credits leads to an increase in the money interest rate. The money supply in the hands of businesses is reduced. ${ }^{42}$ This leads to a relative fall in factor prices and increases the differentials between buying and selling prices, which is in turn the first step towards a recovery.

\footnotetext{
40 See Bean (2004), p. 14.

41 See Rothbard (2000), p. 17-18.

42 Ibidem, p. 18.
} 
Moreover, in a clean and efficient way, the credit restriction wipes out businesses that rely on further credit expansion with artificially low interest rates, i.e., businesses not in line with consumer preferences in a free market. ${ }^{43}$ After the liquidation of these unsustainable investments, the resources employed in the erroneously undertaken projects can be shifted to uses which better satisfy consumer preferences. Consequently, far from being the cause of the recession, a credit crunch, instead, hastens the recovery.

Similarly, the burst of the asset price bubble that causes the credit crunch is not the ultimate cause of the recession. Again, it is the credit expansion that causes the malinvestments and the asset price boom. The burst of the bubble as a trigger of a credit crunch speeds the recovery. Therefore, it is erroneous to start the analysis of the credit crunch with the asset prices boom. Rather, it must start at the root of the phenomenon, which is credit expansion and fractional reserve banking. Herein, the proactive view fails.

Moreover, there is another problem in the aim of the proactive view. By pricking the bubble while it is small, proactivists wants to ensure financial stability. ${ }^{44}$ This raises two questions. First, what is the nature of the financial system that should be rescued? Second and more specifically, can this system ever be stable? Let us turn to the first question. It is true, that the fiat monetary system with fractional reserves might be put into severe trouble by an asset price crash that causes a banking crisis. In the extreme, the system might collapse and in a market process, another

43 It is arbitrary to say that there might be "prudential» projects (in the sense that they would be profitable in a «normal» world with a stable financial system) that would be harmed by the credit contraction. How can a project be «prudential» if it relies on the absence of a credit contraction? How can a project be «prudential» if it relies on the stability of an inherently unstable financial system? The problems of the "prudential» projects are an entrepreneurial error. The alternative to the contraction is to create a new credit expansion. With ever more credit expansion, ever more investment projects become «prudential.» Where is the line of credit expansion where «prudential» projects and unprudential ones can be differentiated? In any case, the projects can go bankrupt quickly, change owners, and begin anew with really prudential plans.

${ }^{44}$ See Bordo and Jeanne (2002), p. 5; or Borio and Lowe (2002), p. 23. 
commodity money might evolve. It is even possible that the traumatic experience of the collapse leads to a sound monetary system, i.e. a commodity standard with $100 \%$ reserves. This experience might immunize the public against tolerating further attempts of the state to manipulate money. Thus, the illusion that credit expansion and fractional reserve banking benefits all market participants might be ended. Even though many might consider the collapse of the monetary system as something to be avoided, one cannot argue from a value-free position that the system should be preserved. The proactivists seem to have smuggled in ethical content. Yet, this content requires justification. In contrast to the proactive position, economists asked to recommend a sound monetary system which does not lead to business cycles might even see an asset price crash as advantageous. Such a recommendation might lead to the end of the existing monetary system.

The other question is, whether the existing system can ever be stable. The fractional reserve banking system backed by a central bank as lender of last resort tends to generate boom and bust cycles by credit expansion. The existing monetary system greatly enlarges the possible fluctuations in the asset price markets. In a fractional reserve system, a bank run leads to the bankruptcy of the bank. This, in turn, can shake the confidence in the liquidity of other banks and trigger more bank runs. Therefore, the system can never be stable, since sudden changes in confidence can put the whole system into jeopardy. The ability of the system is wholly based upon confidence in the permanent liquidity of the banks. However, confidences can change and fractional reserve banks are, strictly speaking, never liquid. Banks within this system are always in danger of bankruptcy. To prevent the bankruptcy of a bank, the central bank is required to intervene, printing as much money as would be necessary to keep the bank solvent. This, of course, would lead then to wild fluctuations of the purchasing power of money, i.e. to instability. Furthermore, it is the fractional reserve banking system that produces the asset price bubbles which the proactive view recommends pricking. Curiously, the proactive view recommends pricking asset price bubbles to preserve the stability of a system 
that is inherently instable. Yet, this does not make the system stable but, at best, only dampens the volatility and extent of the asset price and real economy cycles.

The problem underlying proactivist concerns has been aptly called a "dilemma.» ${ }^{45}$ Indeed, it is the old dilemma that always arises when one starts conducting monetary policy. By increasing the money supply through the loan market, the interest rate is artificially reduced, leading to an intertemporal misallocation of resources and ultimately a recession. Keeping monetary policy expansionary may help to continue the boom, but only at the cost of a greater recession later. The "asset price problem» is a reflection of the very same dilemma. ${ }^{46}$ By not pricking the bubble, the bubble grows and endangers the future stability of the financial system and consumer goods prices. By pricking the bubble, however, the current financial stability is endangered. This «dilemma» can be interpreted as a further step in a long line of interventions by the government in the banking and monetary system. Mises' theory of interventionism is useful in analyzing this long line of interventions. ${ }^{47}$ His theory states that interventions

45 See Bordo and Jeanne (2002, p. 131).

46 This dilemma was recognized earlier. As Benjamin M. Anderson (1979 [first edition 1949], p. 216) states about the Federal Reserve board in the late 1920s: «The Federal Reserve authorities from early 1928 on pursued an inconclusive policy based on three partially conflicting motives: (a) the desire to restrain the use of credit for stock market speculation; (b) the desire not to tighten money in foreign countries and not to pull in more gold from abroad; and (c) the desire not to let money grow tight in business uses at home. The conflict among these policies meant that the efforts at restraint were handicapped and inconclusive, and that the wild speculation ran on for a year and nine months after the restraining efforts began.» (Italics added)

Anderson (1979, pp. 209-210) himself seems to propose a proactive stand as he critiques Gustav Cassel for arguing that the central bank should not take stock market booms into account and tighten credit in response to them: «We were troubled also in 1928-29 by the weird doctrine of Professor Gustav Cassel of Sweden (who had many American followers as well as wide vogue in Europe) that it was the business of central banks to maintain a fixed commodity price level, and that central banks must not concern themselves with the stock market and must not tighten credit to restrain stock market excesses because that would reduce commodity prices.»

See also Wicker (1966, p. 118, 129 and 131) for the differing views among those on the Federal Reserve Board concerning a proactive or reactive stand towards the stock market speculation.

47 Mises' theory of interventionism can be found in Mises (1996), p. 15-56. 
are not stable but must either lead to further interventions or their abolition. The crucial point in Mises' argument is that an intervention leads to unwanted results from the view point of the interventionist, so that later he either takes the intervention away, or tries to fix the problem with more interventions, thereby creating more unwanted consequences.

The starting point of the interventions into the banking system is the allowance and toleration of fractional reserve banking which historically was born by a breach of private law. ${ }^{48}$ The fractional reserve banks are always in danger of losing reserves to other banks that are less expansionistic. This puts the liquidity of expansionistic banks into danger if other banks demand redemption. In order to improve the stability of the fractional reserve banking system, a central bank, constituting another intervention, is installed. This intervention coordinates the credit expansion to prevent losses of reserves, with the central bank acting as a lender of last resort. However, this increases the opportunities to expand credit, leading to greater business cycles. In a recession, bank runs threaten the existence of the fractional reserve system. To fix this threat of bank runs the government has to nationalize the private commodity money and install a fiat money regime in order to prevent bank runs. This fiat money regime provides the banks with even greater security to engage in credit expansion. Hence, the ability to expand and contract credit is enlarged. As a consequence the banking sector is regulated by the central bank. However, credit cycles become more volatile as banks search for monetary innovations. At some point these credit cycles lead to gigantic bubbles in the asset price markets. Since an asset price crash could endanger the stability of this fragile financial system and put the central bank on the spot, other interventions seem to be necessary, that is the central bank's continuous management of asset prices combined with stricter regulations of financial markets and the banking sector. Therefore, the Misesian theory of interventionism can explain why the state

48 See Huerta de Soto (2006), p. 1-134. For the dynamics of state intervention into the monetary system see also Rothbard (1990). Salerno (1991) has coined the term «progression theorem» for this process. 
is inclined to commit continuing interventions into the banking and monetary system. Historically, the next step seems to be a stricter regulation of financial markets and the manipulation of asset prices.

As noted earlier, the collapse of a monetary system is usually considered as something to be avoided. And surely, a government and banks both have an interest in the stability of a financial system. There is no need, however, to assume that the primary interest of the government and of bankers is a stable monetary system. A completely stable market, would in essence, be a conflict of interests. Bankers make great profits by credit expansion and the ability to create money out of thin air; while in a symbiotic manner the government is financed by the credit expansion. This financing of expenditures via credit expansion has an advantage for the government in that it is usually not as unpopular as taxes. The banks are traditionally the biggest investors in asset price markets and provide their customers services related to asset price markets. Hence, the banks profit from the central bank bailing out asset price market investors. A crash would severely hurt the banks and endanger the fractional reserve banking system and asset markets. The financing of government would be disturbed. It is in the vital interest of banks and the government that the central bankers manipulate with asset prices and bail out investors.

\section{Critique of the reactive view}

The reactive view concentrates not on the proactive prevention of bubbles but rather on easing of the consequences of an asset bubble's collapse. As Greenspan (2002, p. 5) states:

«The notion that a will-timed incremental tightening could have been calibrated to prevent the late 1990s bubble is almost surely an illussion. Instead, we noted in the previously cited mid-1999 congressional testimony the need to focus on policies 'to mitigate the fallout when it occurs and, hopefully, ease the transition to the next expansion.'» 
The reactive view extends the proactive position, adding false assumptions to its theory concerning the financial system. In order to refute the proactive view, the reactive view points to problems connected with a proactive policy. Those problems, asserted to be caused by the active pricking of asset price bubbles, are mostly irrelevant from a perspective of economics as a value free science. Instead, such problems concern the practice of monetary policy.

First, those who advocate a reactive approach claim that central bankers would have a justification problem if consumer goods prices would stay stable. ${ }^{49}$ Since credit expansion can be absorbed temporarily by asset price markets or compensated by productivity increases, it is indeed conceivable that during an asset price boom consumer prices do not rise sharply. ${ }^{50}$ Therefore, it is possible to have stable consumer prices and an asset price boom at the same time. In this context, it would be difficult for central bankers to argue for a tightening of monetary policy to prick an asset price bubble. Consumers, content with the price increase of their assets, will argue that the central bank is wrong in pursuing a restrictive monetary policy because consumer prices do not show any signs of inflation. Hence, the public pressure on central bankers not to prick asset price bubbles will be enormous. While the justification problem is irrelevant to the theoretical problem of the connection of asset prices, credit expansion, and the real economy, it is important for the practice of monetary policy. This shows that a strong incentive to continue an expansive monetary policy accompanies the installation of a fiat money system headed by a central bank.

Second, those who support a reactivist policy claim that central bankers cannot know when an asset price bubble occurs. Svensson $(2002$, p. 290) states that «[i]t goes without saying that in most realistic situations, it will be very difficult to judge whether a particular asset-price movement is grounded in expectations about reasonable fundamentals or a bubble...».

\footnotetext{
49 See Conrad and Stahl (2002), p. 492.

50 This has been the case during the «New Economy Boom».
} 
Indeed, there is no clear-cut sign of a persistent asset price boom. The central bank as a central institution does not possess the subjective information necessary to determine when an asset price rise is artificially caused by a credit expansion and when not. In order to forestall any distortions on asset price markets by credit expansion, a central bank would have to manipulate asset prices via its monetary policy simulating how asset prices would form in a market with private money. However, this is impossible, since money has been nationalized and the central bank exists. One simply cannot simulate a free market of money. ${ }^{51}$ Granting this point that the central bank lacks the appropriate knowledge to precisely identify asset price bubbles, it must be recognized that unusually large asset price bubbles might be detected.

Third, the reactive view maintains that the credibility and reputation by a central bank might be in danger, if it tries to target both asset prices and consumer goods prices. It is argued that the central bank would be viewed too interventionist by manipulating asset prices and thereby losing its credibility. ${ }^{52}$ Furthermore, by trying to achieve two aims, the likelihood is greater that the central bank would fail in one of those aims. The two aims might even suggest contradictory policies. ${ }^{53}$ The underlying problem is that the central bank has one instrument (monetary policy) to achieve two aims. For example, consumption good prices might rise while the stock market falls. In this case, the central bank would almost necessary fail in its aim of stabilizing both. Hence, the credibility of the central bank would suffer. The credibility of the central bank is considered a very important factor for the success of its aims. The reputation or credibility concern of the reactive view is indeed justified. By trying to manipulate too many features of the economy the central bank gets into difficulties and contradictory aims. It shows that it is impossible for the central bank to fine-tune the economy.

${ }^{51}$ For the application of the theorem of the impossibility of socialism to money, see Huerta de Soto (2006), p. 503-525.

52 See Mishkin and White (2002), p. 35.

53 See Berger and Kißmer and Wagner (2005), p. 1. 
Another argument that reactivists make is that if monetary policy makers increase interest rates, the stock market might not be affected, but economic activity would be hampered. As Bean (2004, p. 15) states:

[...] a modest increase in interest rates may do little to restrain an asset price boom. But an increase large enough to materially affect the evolution of asset prices is likely to have a significant adverse impact on economic activity.

It is true that the euphoria of the bubble might not be affected in the beginning by small increases in the interest rate. However, the boom will end sooner than without such an increase in the interest rates, since increasing interest rates reduces the net present value of companies and puts projects that rely on lower interest rates in danger. The increase in interest rates that are artificially low does have a healthy effect by purging unsustainable investment projects. The increase has a positive effect on «economic activity» in the sense that it shifts "economic activity» and economic resources from unsustainable adventures to investment projects that are in line with consumer preferences.

Let us now turn to a more substantial problem with the reactive view. The reactive view asserts or at least implies, that it would be possible to avoid the "pricking» of asset price bubbles by prudent monetary policy. Yet, this is an illusion. The only thing that the central bank can achieve is delaying the "pricking" of asset price bubbles through its fostering of further credit expansion via relative interest rate decreases. By continuing credit expansion with higher doses of credit it is possible to maintain an artificial boom in the stock market. Such a reactive policy, which in the beginning avoids a "pricking» of the bubble, enlarges the distortions in the stock market. Later these extortions find their way into the real economy, starting an unsustainable boom. Finally, as this analysis shows, recession must set in when profits in consumer goods industries rise relative to profits in capital goods industries. At the latest, when the real economy slumps into a recession with losses and bankruptcies in capital good industries, the euphoria will vanish and the stock market 
will collapse. The central bank cannot avert this development by simply letting the bubble grow. As credit expansion continues, the growing bubble and growing distortions in the real economy will become ever more sensitive to monetary policy. Hence, at some point only a little slowing down of further credit expansion will be sufficient to start the recession and «prick» the bubble.

There is another implication of reactive policy shared by the mainstream. The mainstream unanimously recommends reacting to an asset price crash with an easing of monetary policy. ${ }^{54}$ However, the stock market crash only manifests the malinvestments that were undertaken some time ago. Finally, errors that were undertaken in the past become apparent and can be taken into account by market participants. Therefore, it is an important sign for the acting individuals that the stock market crashes. One can come back to a healthy and sustainable economic development. Entrepreneurial actions will be characterized by long-term thinking again and the illusion that one could get richer without savings or efforts fades. It must be pointed out, that the errors committed in the past would not disappear if the stock market had not crashed, and that the effects of these errors can not be wiped out by a new credit expansion. In fact, if credit expansion is undertaken to prop up the asset prices, the new credit expansion will eventually flow into the real economy and malinvestments will not be liquidated as quickly as they would have without this propping up, i.e., the errors of the past will not be corrected. Moreover, there will be new malinvestments caused by the credit expansion. New errors will be added on top of the old. Therefore, a restrictive monetary policy after a stock market crash can help to liquidate the malinvestments both quickly and cleanly. Every delay of the stock market crash and the return to sustainable plans of the individuals is bought at the cost of more distortions and errors and consequently, a harsher correction in the future. Again, a final-break down of the stock market and the unsustainable plans of individuals can at best be delayed for some time, but not prevented by propping up asset prices.

54 Zimmermann (2004), p. 112; or Peter (2004), p. 23. The reactive view even seems to imply an expansive monetary policy when an asset price collapse is imminent. See Bean (2004), p. 15. 
Let us turn to a last important element of the reactive view. While the reactive view argues that stock market increases should not be disturbed, it recommends, as explained above, reacting to a crash by an easing of monetary policy. This recommendation entails a bailing out of investors at the asset price markets. This downward safety net for asset prices leads to moral hazard. Investors start to rely on central bankers to react in favor of asset prices when a crash occurs or is expected to occur. As Mueller (2001, p. 1) puts it:

Government and monetary authorities who systematically practice a policy of stabilizing financial assets and business activities by a policy of easy money and bailouts expose individual economic agents to a learning process of diminishing risk perception.

That is, investors expect the central bank to intervene and prop up asset prices. This implicit assurance has aptly been called Greenspan-Put, ${ }^{55}$ named after former Fed chairman Alan Greenspan, who was expected to and did actually intervene whenever a stock market crash loomed. By relying on this insurance, stock market participants make riskier investments. The probability and severity of asset price bubbles are increased. It is important to note that the bailing out of the stock market by credit expansion has, as well, important real effects, since it indirectly works as a safety net for investors in the real economy. These investors know that in a harsh recession with big businesses collapsing, the stock market would collapse as well. In this scenario, central bankers, adhering to a reactive view, would intervene and expand credit, bailing out businesses in need of further credits at an artificially low rate. Hence, the reactive view leads to moral hazard in the real economy as well. ${ }^{56}$

55 See Detken and Smets (2004), p. 9 and p. 30.

56 Moral hazard in the real economy is, of course, also stimulated by the belief that in a recession with businesses «too big to fail» central bankers would bail them out by credit expansion. This moral hazard is complementary to the moral hazard caused by application of the reactive view policy that props up asset prices. 


\section{The boom as an unmistakable indicator of a credit expansion}

After the critique of both the reactive and proactive views we will now turn to the question of how the $\mathrm{ABCT}$ and its connection with asset prices could help monetary policy makers, assuming they want to restrict malinvestments. First, we must keep in mind that only a continuous credit expansion makes a wild persistent stock market boom possible. Hence, the boom is a good and early indicator for an ongoing credit expansion that might not have reached real production yet. In contrast, other indicators of credit expansion often fail. For example, consumer goods prices might not increase at the beginning of a credit expansion. Since productivity might increase at the same time, consumer price indexes might stay stable in periods of credit expansion as shown by the experiences in the 1920s in the U.S.. Also the exchange rate might fail as an indicator for a dangerous increase in credit expansion since other countries might be engaged in a credit expansion as well. Therefore, an ongoing asset price boom is a relatively good indicator of credit expansion. Machlup even regards the stock market boom even as the best indicator of an artificial boom (2002, p. 217), and Robbins (1971), p. 171 , argues that «[...] the banks should pay chief attention to the movements of the security markets...».

This indicator can be improved upon if one looks separately at the stock prices of enterprises located at different points in the production process. In a stable growth process caused by an increase in savings and a corresponding decrease in consumption, the shares of enterprises that produce consumption goods tend to fall while the shares of enterprises that produce capital goods or extract raw materials tend to rise. In an artificial boom, however, consumption does not shrink. The money created by credit expansion is invested in new enterprises without a corresponding reduction of consumption. Therefore, it is possible that both the stocks prices of companies that are located near consumption (consumer goods industries) and the stocks of companies located further away from consumption (capital good industries) soar. The increase in the price of stocks of capital 
goods companies which is not compensated by a decrease in the price of stocks in consumer goods companies indicates an artificial boom. Outlining a stock market indicator, of course, does not tell us how to measure a stock market boom in practice. This might be done by measuring the deviations from an average priceearnings ratio. However, identifying a stock market boom always remains difficult and is a matter of Verstehen, i.e., of an entrepreneurial interpretation.

\section{Implications for monetary policy}

Fractional reserve banking leads to boom and bust cycles caused by credit expansion. This credit expansion can also lead to bubbles in the asset price markets that pose virtually insurmountable problems and «dilemmas» for monetary policy makers. These problems are already inherent in the fractional reserve banking system. The only way to solve the "asset price problem» would be to eradicate the fractional reserve banking system, making room for a sound monetary system to evolve on a 100 percent reserve basis. A 100\% gold standard would be such a monetary system, by definition ruling out credit expansion and thereby, also ruling out business cycles and asset price booms and busts. Monetary policy and consequently, the asset price problem for monetary policy would no longer exist. It is intriguing that this true solution of the asset price problem is not analyzed or even mentioned by either the proactive nor reactive proponents. Their debate is therefore in vain. These proponents seem to be unaware of the easiest, and most straightforward, and apparent solution to the asset price problem.

However, there might be people who would like to preserve the inherently instable fractional reserve banking system that causes boom and busts in the real economy and asset price markets. These people might want monetary policy to restrict malinvestments and the loss of capital. They can draw, from the above reasoning, two main conclusions concerning the treatment of asset prices by the monetary authority that strongly defer from usual neoclassical conclusions. 
First, if there is a stock market boom the central bank should restrict credit. As Lionel Robbins (1971), p. 171-172 states:

If, as soon as there appeared signs of a general boom on security markets, the Central Banks were to take action to bring it to an end, it seems probable that extremes of business fluctuations might be avoided.

That is, the central bank should raise interest rates in order to end the artificial boom. If the credit expansion was only retained in the stock market and has not had real effects on the structure of production, it might even be possible to prevent distortions of the structure of production. By restricting credit the asset prices might, in this case, fall again without distorting the structure of production. Assuming that malinvestments should be minimized, the theory, therefore, would recommend a strong proactive policy, which means that the asset price bubble should always be pricked.

Second, when a stock market crash occurs, an expansionary monetary policy that would prop up asset prices should be avoided; in contrast, a restrictive monetary policy should be adopted. By restricting credit, the central bank would hasten the recovery and the readapting of the structure of production to the preferences of the market participants.

\section{IV CONCLUSION}

$\mathrm{ABCT}$, credit expansion, and asset price booms are closely connected. Real savings, investments, and consumption become discoordinated by the artificial reduction of the interest rate. This will be felt in the asset price markets as well. The error cycle of asset price booms and busts become possible because market participants do not know when the credit expansion has ended, and because market participants believe that credit expansion and central banking stabilization of asset prices are beneficial.

Since ongoing booms are only possible if there is ongoing credit expansion, asset price booms can serve as a good indicator 
for credit expansion. As the analysis has shown, drawing from Austrian theory, one can support the proactive view in favor of pricking asset price bubbles. However, neoclassical economists recommend a proactive stance only in order to maintain the stability of an unsound monetary system, ignoring the liquidation of malinvestments that a restrictive policy might induce. Furthermore, the recommended reaction towards a burst of an asset price bubble has dubious results. An expansive monetary policy can only temporarily maintain the distorted structure of the economy. Though well-intended, such a policy becomes bad medicine. While in contrast, a restrictive monetary policy could purge malinvestments more quickly. Instead of meddling with asset prices, Austrian theory shows a clean way to end asset price booms and busts. To end asset price booms and busts, one has to eliminate their cause - credit expansion. To do this, a sound monetary system must be installed. A traditional Austrian recommendation for monetary reform, ${ }^{57}$ a 100 percent gold standard, would with the restricting of the credit expansion also restrict the likelihood of asset price bubbles. The problem of asset prices for monetary policy would with monetary policy itself disappear.

\section{BIBLIOGRAPHICAL REFERENCES}

Anderson, Benjamin M., 1979. Economics and the Public Welfare: A Financial and Economic History of the United States, 19141946, Indianapolis, In.: Liberty Press.

Bean, Charles, 2004. "Asset Prices, Financial Instability, and Monetary Policy,» American Economic Review, Vol. 94, N.으 2, pp. 14-18.

Berger, Wolfram; Kibmer, Friedrich and Helmut Wagner, 2005. Monetary Policy and Asset Prices: More Bad News for «Benign Neglect», Diskussionsbeitrag der Fernuni Hagen, N.․ 374, February.

57 See Rothbard (1991); and Rockwell (1992); and Huerta de Soto (2006), pp. 557 for extensive descriptions of transition plans towards a $100 \%$ gold standard. 
Bernanke, Ben and Mark Gertler, 2000. «Monetary Policy and Asset Price Volatility,» NBER Working Paper N.․ 7559, february.

Bordo, Michael and Olivier Jeanne, 2002. «Monetary Policy and Asset Prices: Does “Benign Neglect” Make Sense?,» paper presented at the conference: «Stabilizing the Economy: Why and How?» on July $11^{\text {th }}$, www.econweb.rutgers.edu/ bordo/BordoJeanne.pdf.

Bordo, Michael and Oliver Jeanne, 2004. «Boom-Bust in Asset Prices, Economic Instability, and Monetary Policy,» in: Burdekin, Richard and Pierre Siklos (eds.), 2004. Deflation, Cambridge University Press, Cambridge, p. 131-165.

Bordo, Michael and David Wheelock, 2004. «Monetary Policy and Asset Prices: A Look Back at Past U.S. Stock Market Booms,» Federal Reserve Bank of St. Louis Review, November/ December, 86 (6), p. 19-44, research.stlouisfed.org/publications/ review/04/11/BordoWheelock.pdf.

Borio, Claudio and Philip Lowe, 2002. "Asset prices, financial and monetary stability: exploring the nexus,» BIS working papers, No. 114, July, www.bis.org/publ/work114.pdf.

Callahan, Gene and Roger Garrison, 2003. «Does Austrian Business Cycle Theory Help Explain the Dot-Com Boom and Bust?,» Quarterly Journal of Austrian Economics, 6 (2), 67-98.

Cecchetti, Stephen G.; Genberg, Hans; Lipsky, John; and WadhWAnI, Sushil, 2000. Asset Prices and Central Bank Policy, London, UK: International Centre for Monetary and Banking Studies.

Cecchetti, Stephen G., 2002. «The Trouble with Bubbles,» Occasional Essays on Current Policy Issues No. 21 (September $4^{\text {th }}$ 2002). Conrad, Christian and Markus Stahl, 2002. "Asset-Preise als geldpolitische Zielgröße - das Beispiel der USA,» Wirtschaftsdienst, 82, 486- 493.

DetKen, CARsten and Frank SMets, 2004. «Asset Price Booms and Monetary Policy,» ECB Working Paper Series, N.. 364, May, http://www.ecb.int/pub/pdf/scpwps/ecbwp364.pdf.

Goodhart, Charles and Boris Hofmann, 2004. "Deflation, Credit and Asset Prices,» in: Burdekin, Richard and Pierre 
Siklos (eds.), 2004. Deflation, Cambridge University Press, Cambridge, p. 166-188.

GreENSPAN, Alan, 2002. «Opening Remarks,» Rethinking stabilization policy, Federal Reserva Bank of Kansas City, pp. 1-10.

Gruen, David; Plumb, Michael and Andrew Stone, 2003. «How should monetary policy respond to asset-price bubbles?,» ECB Research Discussion Paper, November, www. ecb.int/events/pdf/conferences/gruen-plumbstone.pdf.

HAYEK, Friedrich A. vON, 1934. «The Maintenance of Capital,» Economica, Vol. II, August, Reprinted in: Hayek, Friedrich A. von, 1939. Profits, Interest and Investment - and other Essays on the Theory of Industrial Fluctuations, London, UK: Routledge, 83-134.

Hoppe, Hans-Hermann, 2001. Democracy: the God that failed: the Economics and Politics of Monarchy, Democracy and Natural Order, New Brunswick, NJ: Transaction Publishers.

Huerta DE Soto, Jesús, 2003. «Nota critica sobre la propuesta de reforma de las normas de contabilidad,» Actuarios, N.․21, April/May 2003.

- 2006. Dinero, Crédito Bancario y Ciclos Económicos, Third Revised Edition, Madrid: Unión Editorial (First English edition, Money, Bank Credit and Economic Cycles, Auburn, AL: Ludwig von Mises Institute).

HülsmanN, Guido, 1998. «Toward a General Theory of Error Cycles,» Quarterly Journal of Austrian Economics, 1 (4), 123.

MACHLUP, FRITZ, 2002. Börsenkredit, Industriekredit und Kapitalbildung, Reprint of the First Edition, Frankfurt: Frankfurter Allgemeine Buchverlag.

Mises, LudWIG von, 1996. A Critique of Interventionism, Revised Edition, Irvington-on-Hudson, NY: The Foundation for Economic Education.

- 1998. Human Action, Scholar's Edition, Auburn, AL: Ludwig von Mises Institute.

Mishkin, Frederic and Eugene White, 2002. «U.S. Stock Market Crashes and Their Aftermath: Implications for Monetary Policy,» NBER working paper, N.ㅇ 8992, June. 
Mueller, Antony, 2001. "Financial Cycles, Business Activity, and the Stock Market,» Quarterly Journal of Austrian Economics, 4 (1), 3-21.

Peter, Goetz von, 2004. "Asset prices and banking distress: a macroeconomic approach,» BIS working papers, ‥ 167 , www.bis.org/publ/work167.pdf

RobBINS, LIONEL, 1971. The Great Depression, Second Edition, Freeport, NY: Books For Libraries Press.

RocKWELL JR., LleWELlYN (ed.), 1992. The Gold Standard: Perspectives in the Austrian School, Auburn, AL: Ludwig von Mises Institute.

Rothbard, Murray N., 1990. What Has Government Done to Our Money?, Auburn, AL: Ludwig von Mises Institute.

- 1991. The Case for the 100 Percent Gold Standard, Second Edition, Auburn, AL: Ludwig von Mises Institute.

- 2000. America's Great Depression, Fifth Edition, Auburn, AL: Ludwig von Mises Institute.

- 2001. Man, Economy, and State, Auburn, AL: Ludwig von Mises Institute.

Salerno, Joseph T. 1991. «Two Traditions in Modern Monetary Theory: John Law and ARJ Turgot». Journal des Economistes et des Etudes Humaines, 2, N. 2/3, 337-379.

Skousen, Mark, 2005. Vienna \& Chicago: Friends of Foes?, Washington, DC: Capital Press.

SVEnSSON, LARS, 2002. «Monetary Policy and Real Stabilization,» Proceedings, Federal Reserve Bank of Kansas City, 261312, www.princeton.edu/ svensson/papers/jh02.pdf.

Wicker, Elmus R., 1966. Federal Reserve monetary policy 1917-1933, New York: Random House.

ZimmermanN, Guido, 2004. "Assetpreise und Geldpolitik,» Wirtschaftsdienst, Vol. 84, 105-112. 